\title{
A FOCUS OF FAVUS DUE TO Trichophyton schoenleinii IN RIO GRANDE DO SUL, BRASIL
}

\author{
Shirley M.W. MATTE, Jorge O. LOPES, Ivanir S. MELO \& André A. COSTA BEBER
}

\begin{abstract}
SUMMARY
This paper reports the occurrence of a focus of favus due to Trichophyton schoenleinii affecting seven members of a family, 29 years after the last register of the disease in Rio Grande do Sul.
\end{abstract}

KEYWORDS: Favus; Trichophyton schoenleinii; Rio Grande do Sul.

\section{INTRODUCTION}

Favus is a chronic infection with a dermatophyte fungus characterized by dense scutulum composed of mycelial masses and epithelial debris in hair follicles ${ }^{12}$. Clusters of infected follicles may caused matting of the hair, and after a period of years atrophy of the skin occurs, leaving a permanent alopecia. In most all cases, favus is caused by Trichophyton schoenleinii. This dermatophyte is endemic in Africa and Central Europe, but foci restricted to members of a single family had been reported in the Western hemisphere. These foci are associated to descendants of ancestors who emigrated from endemic area". We report the occurrence of a focus of favus due to. T. schoenleinii affecting seven members of a family, 29 years after the last register of the disease in Rio Grande do Sul (RS).

\section{CASE REPORT}

A 22-year-old married white female, born and living in 15 de Novembro county, RS, came to the Dermatology Department of the Santa Maria University Hospital with a 15 years history of alopecia. The patient was a nourish hygienic woman, and refered the occurrence of an acute severe inflammatory infection of the scalp when she was 7 -year-old. She revealed that her father age 49, her sisters age 19 and 14, her brothers age 9 and 5, and a first cousin age 19 have similar lesions. The origin of the disease was assigned to her great-grandmother, who immigrated from Germany, and had similar disease. On physical examination several areas of cicatricial alopecia could be seen on the scalp, but furfuraceous lesion on temporoparietal left region was observed (Fig. 1). Scales collected from the lesion and mounted in $10 \%$ potas- sium hydroxide demonstrated irregular branched septate hyaline hyphae. Hair pulled from the lesion revealed mass of fragmented hyphae surrounding hair near mouth of follicle, and hyphae within the hair, showing characteristic channeling of $T$. schoenleinii hair infection. Scales and hair cultured on Mycobiotic agar (Difco) incubated at $25^{\circ} \mathrm{C}$, produced slow growing gray colonies, with raised center and irregularly folded surface (Fig. 2). On microscopic examination characteristic favic chandelier were seen. A scalp biopsy revealed inflammatory and reparative alteration, with adnexal atrophy, related to hair infection by a dermatophyte (Fig. 3).

Examination of her husband was normal, her sister age 19 revealed only cicatricial alopecia, but her brothers and cousin presented similar pityroid lesions with direct and cultural results positive for T. schoenleinii. Terbinafine in a dose of $125 \mathrm{mg}$ and $250 \mathrm{mg}$ per day in children and adult respectively, was the drug prescribed. Only the 22-year-old woman adhered to the treatment.

\section{DISCUSSION}

Favus due to T. schoenleinii is usually a family-centered infection that may affect many generations. In familiar focus patients with cicatricial alopecia live together with patients that have a milder form of the disease, named pityroid form. This clinical form is indistinguishable from a seborrheic form of tinea capitis, and contrast with the acute severe infection, characterized by dense scutulum formation, or the impetiginous form. The variation in severity of forms represent an immune response spe-

Hospital Universitário de Santa Maria. Universidade Federal de Santa Maria, Rio Grande do Sul, Brasil.

Correspondence to: Jorge O. Lopes. Departamento de Microbiologia e Parasitologia. Universidade Federal de Santa Maria, 971 !9-970 Santa Marja, RS, Brazil. 
MATTE. S.M.W.: LOPES, J.O.: MELO. I.S. \& COSTA BEBER. A.A. - A focus of favus due to Trichophyton schoenleinii in Rio Grande do Sul, Bratsil. Rev. Inst. Med. trop. S. Paulo, 39(1): 1-3.1997.

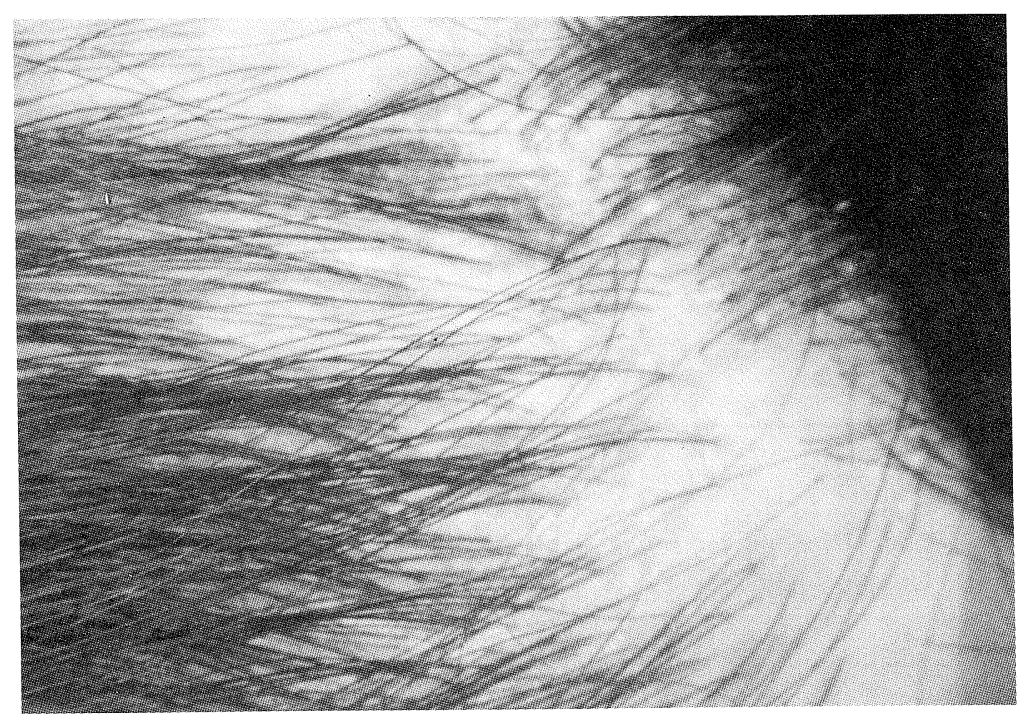

Fig. 1 - Pityroid form of favus: areas of cicatricial alopecia and furfuraceous lesion on temporoparietal left region.

Fig. 2 - Colony of T. schoenleinii; Mycobiotic agar $25^{\circ} \mathrm{C}$, two
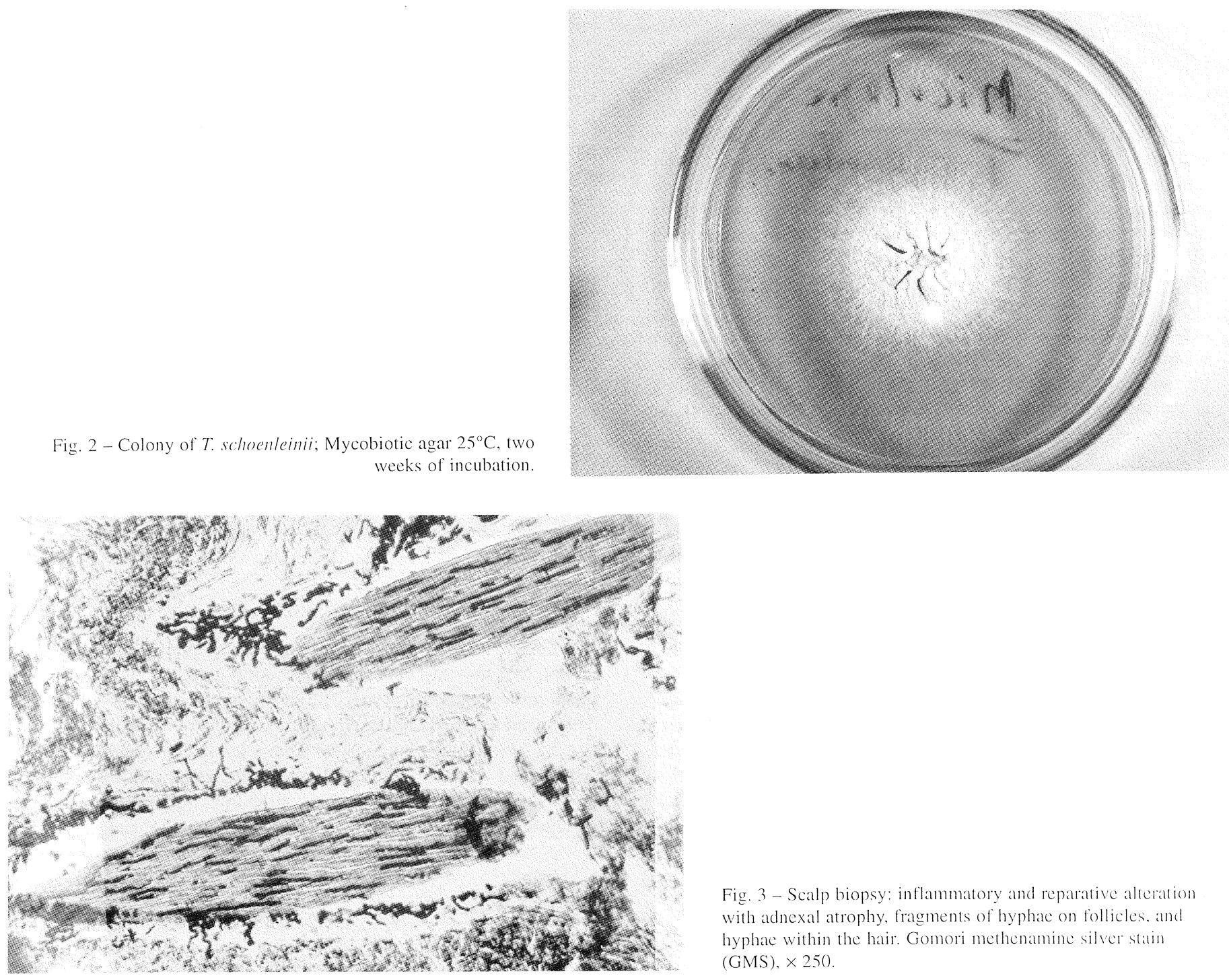

Fig. 3-Scalp biopsy: inflammatory and reparative alteration with adnexal atrophy, fragments of hyphae on follicles. and hyphae within the hair. Gomori methenamine silver stain $(\mathrm{GMS}), \times 250$ 
MATTE, S.M.W.: LOPES, J.O.: MELO, I.S. \& COSTA BEBER. A.A. - A focus of favus due to Trichophyton schoenleinii in Rio Grande do Sul. Brasil. Rev. Inst. Med. trop. S. Paulo, 39(1): 1-3. 1997

cific to each infected patient, involving $\mathrm{T}$-helper/T-supressor lymphocyte interactions ${ }^{3}$. The resulting immune anergy could explain the long standing noninflammatory pityroid form observed in the present report. On the other hand, the symptomless or occult $T$. schoenleinii infection, represented by and accomodation and equilibrium to the host, increase duration of survival, dissemination, and chronicity of the infection ${ }^{13}$. The definitive proof of occult infection would require biopsy for the demonstration of fungi within the hair shaft.

In Rio Grande do Sul favus was first reported by $\mathrm{ASSIS}^{2}$ in 1928. MENDES" in 1962 reported an epidemic focus in Jaguari county, whose agent was studied by FABRICIO et al.? FISCHMAN et al. ${ }^{8}$ in 1963 reported two familiar foci in Jaguari and Santiago, affecting 54 patients. LONDERO et al. ${ }^{10}$ in a tenyear-survey of dermatophytosis diagnosed the disease in 1964, in four children of a family living in Jaguari, known as an endemic area. BOPP \& LEIRIA ${ }^{5}$ in 1967 reported the disease in 47 patients in Candido Godoi county. From that time T. schoenleinii was considered erradicated in Rio Grande do Sul, and only in three occasions the infection was reported in the rest of Brazil1.4.6.

\section{RESUMO}

\section{Um foco de favo por Trichophyton schoenleinii no Rio Grande do Sul}

É relatada a ocorrência de um foco de favo por Trychophyton schoenleinii afetando sete pessoas em uma família, 29 anos após o último registro da doença no Rio Grande do Sul.

\section{REFERENCES}

1. ARMOND. S. - Contribuição ao estudo da tinha favosa em Minas Gerais. Belo Horizonte, 1984. (Dissertação de Mestrado - Faculdade de Medicina da Universidade Federal de Minas Gerais).

2. ASSIS, J.D. - Conclusões da tese "Contribuição ao estudo da mycologia do Rio Grande do Sul". Arq. riogrand. Med., 5:17-18, 1929
3. BABEL, D.E.: ROGERS. A.L. \& BENEKE. E.S. - Dermatophytosis of the scalp incidence, immune response, and epidemiology. Mycopathologia (Den Hiagr) 109:69-73, 1990

4. BELDA JÚNIOR, W.; TAKAHASHI, M.D.F.: AOKI, V. et al. - Tinhal favosiat Relato de ocorrência familiar em Itapecerica da Serra (Município dal Grande Sä́o Palulo). Rev. Inst. Med. trop. S. Paulo, 32:58-62. 1990.

5. BOPP, C. \& LEIRIA, B. - Fivus no Rio Grande do Sul. An. bras. Derm., 42:128.1967.

6. CASTRO, R.M.; MACIEL, F.A.; CARDOSO, A.E.C.\& NANNI. M.E.N - Tinhl favosal em Campinas. Estado de São Paulo. An. bras. Derm., 63:429-432. 1988.

7. FABRICIO, R.; LONDERO. A.T.: FISCHMAN. O. \& RAMOS. C. - Sobre agente etiológico de um foco de favo em Jaguari, no Rio Grande do Sul. In: CONGRESSO SULRIOGRANDENSE DE HIGIENE. 1962

8. FISCHMAN, O.; FABRICIO, R.; LONDERO. A.T. \& RAMOS. C.D. - A timh; fávica no Rio Grande do Sul (Brasil). Rev. Inst. Med. trop. S. Paulo, 5:161164. 1963.

9. KWON-CHUNG, K.J. \& BENNETT, J.E. - Medical mycology. Philadelphia. Leal \& Febiger, 1992. p. 105-161.

10. LONDERO, A.T.: RAMOS. C.D. \& LOPES, J.S. - A ten-year survey of the cutaneous mycoses in the state of Rio Grande do Sul (Brasil). I. Dermatophytoses. Rev. Inst. Med. trop. S. Paulo, 12:339-342, 1970.

11. MENDES, J.J.P. - Achado de um foco de tinha favosa no Rio Grande do Sul CONGRESSO SULRIOGRANDENSE DE HIGIENE. 1962.

12. ODDS, F.C.; ARAI, T.: DISALVO, A.F et all, - Nomenclature of fungal diseases a report and recommendation from a subcommittee of the International Society for Human and Animal Mycology (ISHAM). J. med, vet. Mycol., 301:1-10. 1992

13. RIPPON, J.W. - Medical mycology. The pathogenic fungi and the pathogenic actinomycetes. 3. ed. Philadelphia, W. B. Saunders, 1988. p. 169-275.

Recebido para publicação em 25/10/1996

Aceito para publicaçĩo em (08/01/1997 
